\title{
BOTRYTIS GENUS FUNGI AS CAUSAL AGENTS OF LEGUME DISEASES: A REVIEW
}

\author{
Elīna Brauna-Morževska ${ }^{1,2}$, Biruta Bankina ${ }^{1}$, Jānis Kaṇeps ${ }^{1}$ \\ ${ }^{1}$ Latvia University of Life Sciences and Technologies, Latvia \\ ${ }^{2}$ Institute of Plant Protection, Latvia \\ elina.brauna.morzevska@laapc.lv
}

\begin{abstract}
Grain legumes are important crops for the diversification of European farming system. In Latvia, the areas of faba beans (Vicia faba) and field peas (Pisum sativum) are increasing and legumes that have not been previously cultivated are sown. Globally, the important causal agent of legume diseases belongs to the genus Botrytis. Botrytis spp. cause significant losses in faba beans and infect a wide range of legume crops. Currently, the composition, pathogenicity and biological characteristics of Botrytis species in legumes in Latvia are not known. The aim of this study was to summarize the information about Botrytis spp. on legumes, using monographic method. The researches carried out all over the world show a high genetical diversity of Botrytis cinerea. Non-host specific B. cinerea has been found on 586 plant genera, including many legume crops. $B$. cinerea causes gray mold on leaves and pods of field peas, gray mold on pods of faba beans, and chocolate spot of faba bean leaves. B. fabae can infect plants from Fabaceae family. $B$. fabiopsis is known as a pathogen of faba beans. B. fabiopsis has been observed in Latvia, but no information is available on its presence in Europe. B. pseudocinerea has been found on beans, peas, and clover (Trifolium). Some other Botrytis spp. have been detected on legumes; however, their occurrence and importance are not clear. Summary of existing knowledge about Botrytis spp. on legumes is necessary to continue investigations about the diversity and economic importance of Botrytis spp. in legumes.
\end{abstract}

Key words: cool season legumes, faba beans, chocolate spot, gray mold.

\section{Introduction}

Legumes is an important crop all over Europe, and sowing areas have been increasing during the last years. Leaf and pod diseases is one of the most important yieldlimiting factors. Diseases caused by Didymella spp., Fusarium spp., Sclerotinia sclerotiorum, Alternaria spp., and Stemphylium spp. are widespread and harmful all over the world. The occurrence of pathogens depends on hosts and meteorological conditions, but fungi from the genus Botrytis infect all species of Fabaecea. Botrytis is one of the most studied necrotrophic fungi; nevertheless, it can cause considerable economic losses - pathogenicity and biological properties of different Botrytis species are still unclear. A high genetical and morphological diversity has been observed within this genus; therefore, knowledge of Botrytis species and their life cycles is important. The aim of this study was to summarize the information about Botrytis species, their harmfulness and legume hosts, to determine the necessity for future research in Latvia.

\section{Materials and Methods}

In the present study, the monographic method was used. The literature on the biology and taxonomy of Botrytis spp. and the diseases they cause was analysed. The results of research on Botrytis species in legumes carried out in different parts of the world were summarized.

\section{Results and Discussion}

Importance of legumes in Europe and Latvia

Cropping systems in Europe are heavily dominated by cereals and oilseed rape (Brassica napus). These two crop groups have the highest profit margins and therefore are favoured by European farmers. Unfortunately, this is one of the main reasons why European cropping systems lack crop diversity. Legume grain crops provide various benefits for cropping systems from which the most notable is the reduced need for synthetic fertilisers (Watson et al., 2017).

Grain legumes are slowly regaining their position in the European agriculture. Most of the legumes that are bred in Europe are field peas (Pisum sativum), faba beans (Vicia faba), sweet lupines (Lupinus albus), chickpeas (Cicer arietinum), lentils (Lens culinaris), and vetches (Vicia sativa) (Eurostat, 2018). With political support of the European Union, the total sown area of grain legumes in Europe is increasing. In the last 10 years, the area of peas has almost doubled - from 1.5 million ha in 2007 to 2.7 million ha in 2017. A more rapid expansion is seen in the niche of grain legumes such as lentil and chickpea. The area of chickpea fields has seen rapid expansion: in 2007, chickpea area was only 67.6 thousand ha, whereas in 2017, it covered 562.6 thousand ha. The development of the area of lentil is not quite as rapid as that of chickpea; however, the growth is still considerable - from 37.3 thousand ha in 2007 to 241.9 thousand ha in 2017. Soybean (Glycine max) is one of the most important and widespread grain legumes worldwide, e.g., in Europe, from 2007 to 2017, soybean area tripled - from 1.9 million ha to 5.7 million ha. Lupine is the only grain legume in Europe whose sown areas start to decrease - after reaching its peak in 2015, when the lupine area was 370 thousand ha, it fell down to 274.4 thousand ha in 
2017. In countries where soybean or pea growing is not suitable or causes inconveniences in the planning of harvesting, faba bean takes an important place in grain legume proportion (FAO, 2017). Faba bean is a valuable legume crop, which can be grown as a grain crop or a green-manure legume in numerous cropping systems across the globe. The seeds are used for human consumption or animal feed and are highly nutritious because of the high protein content (up to $35 \%$ ) and the great diversity of nutrient and bioactive compound content (Karkanis et al., 2018). Faba bean is a typical cereal pre-crop in the European cropping systems and is usually followed by one or two cereals (Karkanis et al., 2018). Despite the positive characteristics of faba bean, its global sown area declined from 3.7 million ha in 1980 to 2.4 million ha in 2006 , and from then, there have been no considerable changes in the global sown area of faba bean (FAO, 2019). In contrast, the total area of faba beans in Latvia, due to changes in the agricultural policy of the European Union, has started to grow rapidly - from 4.4 thousand ha in 2013 to 42.5 thousand ha in 2017 (Central Statistical Bureau of Latvia, 2018).

In Latvia, sowings of faba beans and field peas are increasing, and lupines and vetches are grown in small areas (Central Statistical Bureau of Latvia, 2018). Lucerne (Medicago sativa), lupine, red clover (Trifolium pratense), white clover (Trifolium repens), alsike clover (Trifolium hybridum), fodder galega (Galega orientalis) (also common as eastern galega), and honey clover (Melilotus albus) are grown as fodder legumes and herbaceous forage under the agronomical and ecological conditions of Latvia (Karklins \& Lipenite, 2015).

Diseases is one of the most important factors that limit legume production. There are several leaf and pod diseases caused by different pathogens (Didymella spp., Fusarium spp., Sclerotinia sclerotiorum, Alternaria spp., and Stemphylium spp.), but the most important diseases are caused by fungi from the genus Botrytis, which infects all species of legumes. Diseases, which are caused by these pathogens are the most widespread also in Latvia (Pluduma-Paunina et al., 2018).

Taxonomy and phylogeny of Botrytis genus

Botrytis spp. are worldwide-distributed plant pathogens with a high genetic diversity. Botrytis genus is classified in the kingdom Fungi, phylum Ascomycota, subphylum Pezizomycotina, class Leotiomycetes, order Helotiales, family Sclerotiniaceae. There is also sexual stage - Botryotinia spp., asexual name Botrytis should be used according to the rules of the International Code of Nomenclature (Rossman, 2014). The genus Botrytis includes about 30 species, one hybrid species B. allii (B. byssoidea $\times$ B. aclada), and species complexes (Yohalem, Nielsen, \& Nicolaisen, 2003; Walker, 2016); investigations in taxonomy are still continuing.

The majority of Botrytis species were described at the end of the $19^{\text {th }}$ and in the $20^{\text {th }}$ centuries on the basis of fungal morphology. Botrytis spp. have high morphological diversity - colonies in pure culture vary in colour and morphology. Species are difficult to distinguish morphologically; therefore, molecular identification methods succeed in discovering new species and compiling phylogenetic trees. New species are discovered and described occasionally worldwide in different crops and wild plants (Zhang et al., 2010a; Li et al., 2012). At least seven species have been found or differentiated in the last decade (Walker, 2016).

Botrytis spp. were grouped into two distinct phylogenetic groups (clades) by M. Staats et al. (2005) using combined phylogenetic analysis of three protein-coding genes. Clade 1 includes species that infect dicots, but species from Clade 2 infect either dicots or monocots. Since the establishment of the clades, several new species have been described. At this moment, Clade 1 includes non-host-specific $B$. cinerea and $B$. pseudocinerea and host-specific species $B$. fabae, $B$. calthae, $B$. sinoviticola and $B$. californica. Botrytis species from different subclades, for example B. fabae and B. fabiopsis, can infect one hostplant (Zhang et al., 2016). Researches are still in progress to find genes for the identification of species from both clades (Hyde et al., 2014).

Botrytis species are usually named depending on the host plant name. However, it has been found that host and pathogen phylogenies are not congruent (Staats, van Baarlen, \& van Kan, 2005). It proves that both organisms do not co-evaluate to match resistance genes in host with virulence genes in the pathogen. Host shifts explain the low congruence between Botrytis species and their hosts (Staats, van Baarlen, \& van Kan, 2005).

Characterization of Botrytis genus as a plant pathogen

Fungi of the genus Botrytis might have asexual (anamorph) and sexual (teleomorph) development stages of the life cycle. In asexual stage, fungi produce macroconidia and microconidia. The majority of Botrytis species produce sclerotia, which are able to overwinter and survive in extreme conditions. Usually, sclerotia germinate, produce mycelium and conidia, and continue asexual stage. To induce the sexual reproductive cycle and produce apothecia, microconidia should fertilize sclerotia (Faretra \& Antonacci, 1987; Fukumori, Nakajima, \& Akutsu, 2004). Not all Botrytis species produce ascospores. It has been observed that the sexual stage disappears because of negative selection (Willetts, 1997). The ascospores need moisture and have low UV-tolerance (Willetts, 1997). This confirms the necessity for additional research of Botrytis spp. in different regions 
of the globe with various meteorological conditions.

All Botrytis species are necrotrophs and kill plant cells to metabolize them. Most studied is the pathogenesis of $B$. cinerea, but the infection process is similar to other Botrytis spp. The pathogen is able to penetrate through the plant cuticle or stromata openings. Fungi are opportunists and often infect damaged tissues or sites infected by other pathogens (Kars \& van Kan, 2007). Botrytis spp. produce enzymes (oxidases, cutinases, and lipases) to penetrate into plant (Tenberge, 2007). Epidermal cells are destroyed by metabolites such as laccases, proteases, and pectinases. The pathogen causes programmed host-plant cell death to attack and take the nutrients.

There are known several Botrytis spp. that have two forms of the disease - aggressive and nonaggressive (Price, 1970; Hargreaves, Mansfield, \& Rossall, 1977; Harrison, 1981). Optimal weather conditions can cause phase transformation, resulting in large-scale damage to plants in the form of small restricted spots. During prolonged periods of high humidity and moisture, on the leaves of faba beans, aggressive forms of chocolate spot disease have been observed (Park \& Lopetinsk, 1999; Kaur et al., 2018).

Botrytis species are necrotrophic facultative pathogens; however, recent studies have shown the ability of some species to live in plant tissue as endophytes. Six undescribed haplotypes of Botrytis have been found during the studies (Shipunov et al., 2008). Many other undescribed species could be concealed in plant tissues as endophytes without causing any symptoms of infection.

Botrytis spp. in legumes

Botrytis fungi have been observed worldwide everywhere the host plants grow (Jarvis, 1977). As Y. Elad et al. (2016) summarized, Botrytis spp. have been recorded on 596 genera of vascular plants. In the same study, the authors suggest that Botrytis occurrence is related to the softness and tenderness of plant tissues. Leaves of legumes mainly are thick and brittle, and any injuries as mechanical or by insects can induce Botrytis infection (Williamson et al., 2007). Drought stress makes legumes weak and easily attacked by pathogens, which does not cause damages in normal growing conditions (Ahmed et al., 2011).

At present, only two species are known that are not strictly specialized plant pathogens $-B$. cinerea (can infect more than 235 plant species of eudicotyledons) and B. pseudocinerea, that have multiple plant hosts (Williamson et al., 2007; Walker et al., 2011; Elad et al., 2016). B. cinerea has been found on 586 plant genera (Elad et al., 2016). B. fabae is able to infect plants from several plant genera, but all of them are related to Fabaceae family. Other Botrytis species are specialized pathogens that are able to infect one plant species or a few species from one genus.

\section{B. cinerea}

The information on the occurrence of $B$. cinerea Pers. in Fabaceae plant family was collected by Y. Elad et al. (2016). B. cinerea causes gray mold on lentils (Davidson et al., 2004; Tivoli et al., 2006), chickpeas (Pande et al., 2001; Davidson et al., 2007), vetches, beans, peas, clover (Grigaliūnaitè, 2001), galega, soybean, and severe species of Lupinus genus: L. albus, L. angustifolius, L. hirsutus, L. luteus, $L$. mutabilis, L. polyphyllus, $L$. $\times$ regalis. B. cinerea leaf blight and gray mold have been found on eastern clover (Trifolium dasyurum) (Loi et al., 2007), white clover and subterranean clover (Trifolium subterraneum) (Elad et al., 2016), honey clover, and has been isolated from lesions on roots (Cormack, 1946). B. cinerea causes blossom blight in lucerne (Huang, Kokko, \& Erickson, 1999; Li et al., 2004).

$B$. cinerea causes grey mold on field pea pods (Dobson \& Heath, 1991) and has been isolated from pea flowers (Ma \& Michailides, 2005). Gray mold of peas, mostly on leaves, has been commonly noted during wet seasons in Canada (Basu et al., 1973). $B$. cinerea infects flowers and pods of bean (Deverall \& Wood, 1961; Davidson et al., 2007) and leaves (Zhang et al., 2010). Different isolates of B. cinerea may significantly differ in pathogenicity on various host plants (Mirzaei et al., 2009). Diseases caused by $B$. cinerea are difficult to control, because they have many host plants that act as a source of infection.

Symptoms of gray mold caused by $B$. cinerea are similar on different hosts. The infection develops on leaves, plant stem, crown, flowers and pods, and, as a result, the amount and quality of yield reduce or the whole plant can dry out (Bayaa \& Erskine, 1998; Taylor et al., 2007). Botrytis spp. has been isolated from discolored and shrivelled seeds (Kaiser, 1992). Disease symptoms are brown or blanched water-soaking lesions on leaves and fruits. Grey masses of conidia cover lesions on plants and pods (Bayaa \& Erskine, 1998). Conidia land on flowers, germinate, and the infection penetrates into the closely related plant tissues (Biddle \& Cattlin, 2007); therefore, pods are often infected. Cool and moist weather conditions are favorable for the spreading of infection through the plant. More harmful are early infections - as a result of infection and enzymatic degradation, considerable number of lesions may occur on plants (Emden, Ball, \& Rao, 1988).

B. fabae

B. fabae is one of the most studied pathogen of faba beans; however, it is able to infect plants from Fabaceae plant family and has been also found on the genera of Vicia, Pisum, Lens, Phaseolus, and Trifolium (Jarvis, 1977; You et al., 2009; Elad et al., 2016). B. fabae has been recorded on common vetch. Chocolate spot caused by $B$. fabae has been observed on field peas and eastern clover (Elad et al., 2016). 
Chocolate spot caused by Botrytis spp. is the most common and important disease of faba beans. $B$. fabae is able to infect all overground plant parts, and, likewise, $B$. cinerea is worldwide distributed. $B$. fabae is more aggressive for faba beans because of its ability to attack, penetrate and metabolize plant tissues as a specialized pathogen (Jellis \& Bond, 1980; Davidson et al., 2007). Symptoms are numerous redto-dark brown spots, generally on leaves and pods. The infection causes leaf damage, seed and pod reduction, or total crop failure at severe epidemics. In cool and humid conditions, small spots merge into larger lesions (Harrison, 1981). Prolonged wet conditions, when relative humidity is $92-100 \%$, are more favorable for chocolate spot development (Harrison et al., 1984; Davidson et al., 2007). Faba bean infection at the growth stages of flowering and early pod development causes a significant reduction in seed yield from the plant and pod number decrement (Griffiths \& Amin, 1977). Recorded yield losses in different parts of the world have reached $50-90 \%$. The yield losses may even reach $100 \%$ if the yield formation is disturbed (Davidson et al., 2007).

Optimal temperature of $B$. fabae growth, sporulation, and development is $22{ }^{\circ} \mathrm{C}$ (Terefe et al., 2015).

\section{B. fabiopsis}

For the first time, B. fabiopsis was described in China by J. Zhang et al. (2010). Symptoms caused by unknown species on faba bean leaves were similar to $B$. fabae lesions but smaller than $B$. cinerea lesions. Morphological characteristics differed between the species. Mycelial growth temperature ranged between $5^{\circ} \mathrm{C}$ and $10^{\circ} \mathrm{C}$, and the optimal temperature was $20^{\circ} \mathrm{C}$. The authors report that $B$. fabiopsis infected faba beans and was not found on other crops near the bean field, unlike $B$. cinerea that could infect some winter crops like peas, wheat (Triticum), and oilseed rape. B. fabiopsis is incompletely studied, and there is no information available on the presence of $B$. fabiopsis in Europe. The occurrence of $B$. fabiopsis in other legumes is unknown, and no researches have been made after detecting the new species in China. The identification of the causal agent of chocolate spot under field conditions is impossible; therefore, DNA-based analyses are necessary for species identification. Recent studies of chocolate spot of faba beans show that B. fabiopsis has been found in Latvia (Bankina et al., 2017).

\section{B. pseudocinerea}

Earlier B. pseudocinerea has been classified as part of $B$. cinerea species complex or Group I of B. cinerea sensu lato (Leroux et al., 2002; Beever \& Weeds, 2007). Fournier et al. (2003) found genetic differentiation between both groups. The first time the species was described by Walker et al. (2011), who found the fungus in French vineyards in complex with
B. cinerea. This complex can be observed in faba beans and also on peas and in clover. Five strains of $B$. pseudocinerea were found in a faba bean field in Germany (Plesken et al., 2015). B. pseudocinerea and $B$. cinerea differ in resistance pattern to fungicides (Fournier et al., 2003).

$B$. pseudocinerea is different from $B$. cinerea genetically, but similar in morphology. No significant morphological differences were found between B. cinerea and B. pseudocinerea (Fekete et al., 2012).

$B$. pseudocinerea showed unique overlapping between isolates in vegetative compatibility tests, possibly due to the low genetic diversity (Fekete et $a l ., 2012)$. Also, gene transfers between $B$. cinerea and B. pseudocinerea strains can be possible, as E. Fekete et al. (2012) suggested.

Other species

B. caroliniana was detected on blackberries in 2010 (Li et al., 2012). Pathogenicity tests showed the ability of $B$. caroliniana to infect faba bean leaves. Also A. S. Walker (2016) suggested, based on unpublished data, that probably $B$. caroliniana can be pathogenic to faba beans. $B$. caroliniana is genetically closely related to $B$. fabiopsis and they can infect faba beans (Li et al., 2012).

B. anthophila was discovered in red clover in 1913. The fungus develops on plant flowers and petals and infects seeds. B. anthophila was found on red clover flowers and seeds in Lithuania (Grigaliūnaitè, 2001).

B. pyriformis could infect faba bean leaves in vitro during pathogenicity tests using agar plugs with mycelium and conidia suspension (Zhang et al., 2016). There is no information about the occurrence of the fungus on broad beans in nature.

Pathogenicity tests showed the ability of $B$. aclada, B. euroamericana, and B. paeoniae to form lesions on faba bean leaves (Garfinkel et al., 2017). B. aclada is a specialized pathogen of onion (Allium сера) but also could cause primary lesions on the non-host plant that were significantly smaller than B. cinerea, B. euroamericana, and B. paeoniae caused lesions. The role of $B$. euroamericana in broad beans is unclear, and no further researches have been made to determine its pathogenicity in field conditions.

\section{Conclusions}

1. Pathogens from genus Botrytis are common causal agents of diseases of different legumes cultivated in Latvia, Europe, and worldwide. Studies show that one legume crop can be infected with several Botrytis species, which differ in their pathogenicity and aggressiveness.

2. B. cinerea, B. fabae, and B. fabiopsis are faba bean pathogens, but their significance should be clarified. B. pseudocinerea has been found on faba beans in field conditions, and it might 
be a potential pathogen of different legumes. B. caroliniana and B. euroamericana infected faba beans during pathogenicity tests in vitro. B. aclada and B. paeoniae formed primary lesions on faba bean leaves, but their role in infection of legumes is uncertain.

3. Basic knowledge about diversity of Botrytis spp., their distribution and biological properties is required to understand the life cycles of the species and to establish an economically and biologically based control of the causes of this species diseases.

4. Further investigations are required to determine Botrytis species on legumes in Latvia, investigate the occurrence and pathogenicity of the fungi and select plant protection methods to control Botrytis infection in legumes.

\section{References}

1. Ahmed, S., Muhammad, I., Kumar, S., Malhotra, R., \& Maalouf, F. (2011). Impact of climate change and variability on diseases of food legumes in the dry areas. In Food security and climate change in dry areas, 1-4 February 2010 (pp. 157-165). Amman, Jordan: International Center for Agricultural Research in Dry Areas.

2. Bankina, B., Bimšteine, G., Neusa-Luca, I., Roga, A., \& Fridmanis, D. (2017). Less known species of Botrytis spp. - the causal agents of faba bean chocolate spot. In XX Symposium of Baltic Mycologists and Lichenologists, 25-29 September 2017 (p. 27). Gdansk, Poland: The University of Gdansk.

3. Basu, P.K., Crete, R., Donaldson, A.G., Gourley, C.O., Haas, J.H., Harper, F.R., ... Zimmer, R.C. (1973). Prevalence and severity of diseases of processing peas in Canada, 1970-71. Can. Plant Dis. Surv, 53(4).

4. Bayaa, B., \& Erskine, W. (1998). Diseases of lentil. In Allen, D.J., \& Lenne, J.M. The Pathology of Food and Pasture Legumes (pp. 423-472). CAB International, Wallingford, Oxon, UK.

5. Beever, R.E., \& Weeds, P.L. (2007). Taxonomy and genetic variation of Botrytis and Botryotinia. In Botrytis: Biology, pathology and control (pp. 29-52). Springer, Dordrecht.

6. Biddle, A.J., \& Cattlin, N.D. (2007). Pests, Diseases and Disorders of Peas and Beans: A Colour Handbook. CRC Press.

7. Central Statistical Bureau of Latvia. (2018). Central Statistical Bureau of Latvia database. Retrieved January 10, 2019, from http://data1.csb.gov.lv/pxweb/lv/lauks/lauks_03Augk_ikgad/LAG020. px/?rxid=1ff62355-7429-477d-834d-2c2ec912ef93

8. Cormack, M.W. (1946). Sclerotinia Sativa, and Related Species, as Root Parasites of Alfalfa and Sweet Clover in Alberta. Scientific Agriculture, 26(9), 448-459. DOI: 10.4141/sa-1946-0049.

9. Davidson, J.A., Pande, S., Bretag, T.W., Lindbeck, K.D., \& Krishna-Kishore, G. (2007). Biology and management of Botrytis spp. in legume crops. In Botrytis: biology, pathology and control (pp. 295-318). Springer, Dordrecht. DOI: 10.1007/978-1-4020-2626-3_16.

10. Deverall, B.J., \& Wood, R.K.S. (1961). Infection of bean plants (Vicia faba L.) with Botrytis cinerea and B. fabae. Annals of Applied Biology, 49(3), 461-472. DOI: 10.1111/j.1744-7348.1961.tb03638.x.

11. Elad, Y., Pertot, I., Prado, A.M.C., \& Stewart, A. (2016). Plant hosts of Botrytis spp. In Botrytis-the fungus, the pathogen and its management in agricultural systems (pp. 413-486). Springer, Cham. DOI: 10.1007/978-3-319-23371-0 20.

12. Emden, H.F., Ball, S.L., \& Rao, M.R. (1988). Pest, disease and weed problems in pea, lentil, faba bean and chickpea. Current Plant Science and Biotechnology in Agriculture, 519-534. DOI: 10.1007/978-94009-2764-3_44.

13. Eurostat. (2018). Main annual crop statistics. Eurostat, last update: 04.12.2018. Retrieved January 10, 2019, from https://ec.europa.eu/eurostat/statistics-explained/index.php/Main_annual_crop_statistics.

14. Faretra, F., \& Antonacci, E. (1987). Production of apothecia of Botryotinia fuckeliana (de Bary) Whetz. under controlled environmental conditions. Phytopathologia mediterranea, 29-35.

15. FAO (2017). FAOSTAT Database. Food and Agriculture Organization of the United Nations. Retrieved January 23, 2019, from www.fao.org/faostat/.

16. Fekete, É., Fekete, E., Irinyi, L., Karaffa, L., Árnyasi, M., Asadollahi, M., \& Sándor, E. (2012). Genetic diversity of a Botrytis cinerea cryptic species complex in Hungary. Microbiological Research, 167(5), 283-291. DOI: 10.1016/j.micres.2011.10.006.

17. Fournier, E., Levis, C., Fortini, D., Leroux, P., Giraud, T., \& Brygoo, Y. (2003). Characterization of Bchch, the Botrytis cinerea homolog of the Neurospora crassa het-c vegetative incompatibility locus and its use as a population marker. Mycologia, 95, 251-261. DOI: 10.1080/15572536.2004.11833110.

18. Fukumori, Y., Nakajima, M., \& Akutsu, K. (2004). Microconidia act the role as spermatia in the sexual reproduction of Botrytis cinerea. Journal of General Plant Pathology, 70(5), 256-260. DOI: 10.1007/ s10327-004-0124-9. 
19. Garfinkel, A.R., Lorenzini, M., Zapparoli, G., \& Chastagner, G.A. (2017). Botrytis euroamericana, a new species from peony and grape in North America and Europe. Mycologia, 109(3), 495-507. DOI: $10.1080 / 00275514.2017 .1354169$.

20. Griffiths, E., \& Amin, S.M. (1977). Effects of Botrytis fabae infection and mechanical defoliation on seed yield of field beans (Vicia faba). Annals of Applied Biology, 86(3), 359-367. DOI: 10.1111/j.17447348.1977.tb01850.x.

21. Grigaliūnaite, B. (2001). Fungi of the genus Botrytis P. Micheli: Pers. plants in Lithuania. Biologija, 3, 14-17.

22. Hargreaves, J.A., Mansfield, J.W., \& Rossall, S. (1977). Changes in phytoalexin concentrations in tissues of the broad bean plant (Vicia faba L.) following inoculation with species of Botrytis. Physiological Plant Pathology, 11(3), 227-242.

23. Harrison, J.G. (1981). Chocolate spot of field beans in Scotland. Plant Pathology, 30(2), 111-115. DOI: 10.1111/j.1365-3059.1981.tb01237.x.

24. Harrison, J.G. (1984). Effect of humidity on infection of field bean leaves by Botrytis fabae and on germination of conidia. Transactions of the British Mycological Society, 82(2), 245-248. DOI: 10.1016/ S0007-1536(84)80066-2.

25. Huang, H.C., Kokko, E.G., \& Erickson, R.S. (1999). Infection of alfalfa pollen by Botrytis cinerea. Botanical Bulletin of Academia Sinica, 40.

26. Hyde, K.D., Nilsson, R.H., Alias, S.A., Ariyawansa, H.A., Blair, J.E., Cai, L., ... Gorczak, M. (2014). One stop shop: backbones trees for important phytopathogenic genera: I (2014). Fungal Diversity, 67(1), 21-125. DOI: 10.1007/s13225-014-0298-1.

27. Jarvis, W.R. (1977). Botryotinia and Botrytis species: taxonomy, physiology, and pathogenicity, No. 15.

28. Jellis, G.J., \& Bond, D.A. (1980). Observations on the incidence of Botrytis pod rot on Vicia faba. Plant Pathology, 29(2), 66-69. DOI: 10.1111/j.1365-3059.1980.tb01182.x.

29. Kaiser, W.J. (1992). Fungi associated with the seeds of commercial lentils from the US Pacific Northwest. Plant Disease, 76(6), 605-610. DOI: 10.1094/PD-76-0605.

30. Karkanis, A., Ntatsi, G., Lepse, L., Fernandez, J.A., Vagen, I.M., Rewald, B., ... Savvas, D. (2018). Faba Bean Cultivation - Revealing Novel Managing Practices for More Sustainable and Competitive European Cropping Systems. Front Plant Sci, 9, 1115. DOI: 10.3389/fpls.2018.01115.

31. Kars, I., \& van Kan, J.A. (2007). Extracellular enzymes and metabolites involved in pathogenesis of Botrytis. In Botrytis: Biology, pathology and control (pp. 99-118). Springer, Dordrecht.

32. Kaur, S., Reid, P., Harker, K.N., Meers, S., Thomas, J.E., Chatterton, S., \& Carcamo, H. (2018). Effect of Lygus spp. and Botrytis spp. on faba bean (Vicia faba L.) seed quality - are there insect-pathogen interactions? Canadian Journal of Plant Science. DOI: 10.1139/cjps-2018-0074.

33. Li, G.Q., Huang, H.C., Acharya, S.N., \& Erickson, R.S. (2004). Biological control of blossom blight of alfalfa caused by Botrytis under environmentally controlled and field conditions. Plant disease, 88(11), 1246-1251. DOI: 10.1094/PDIS.2004.88.11.1246.

34. Li, X., Kerrigan, J., Chai, W., \& Schnabel, G. (2012). Botrytis caroliniana, a new species isolated from blackberry in South Carolina. Mycologia, 104(3), 650-658. DOI: 10.3852/11-218.

35. Līpenīte, I., \& Kārkliņš, A. (2015). Tauriņziežu audzēšanas vides riski (Cultivation of leguminous crops and environmental risks). Proceedings of the Scientific and Practical Conference 'Harmonious Agriculture', 24-37. 1pp. (in Latvian)

36. Loi, A., Nutt, B.J., Revell, C.K., \& Snowball, R. (2007). AGWEST Sothis: Trifolium dasyurum (eastern star clover). Australian Journal of Experimental Agriculture, 47(12), 1512. DOI: 10.1071/ea07035.

37. Ma, Z., \& Michailides, T.J. (2005). Genetic Structure of Botrytis cinerea Populations from Different Host Plants in California. Plant Disease, 89(10), 1083-1089. DOI: 10.1094/pd-89-1083.

38. Mirzaei, S., Mohammadi Goltapeh, E., Shams-Bakhsh, M., Safaie, N., \& Chaichi, M. (2009). Genetic and Phenotypic Diversity among Botrytis cinerea Isolates in Iran. Journal of Phytopathology, 157(7-8), 474-482. DOI: 10.1111/j.1439-0434.2008.01518.x.

39. Pande, S., Singh, G., Rao, J.N., Bakr, M.A., Chaurasia, P.C.P., Joshi, S., ... Gowda, C.L. (2001). Integrated management of Botrytis gray mold of chickpea. India: International Crops Research Institute for the SemiArid Tropics.

40. Plesken, C., Weber, R.W., Rupp, S., Leroch, M., \& Hahn, M. (2015). Botrytis pseudocinerea is a significant pathogen of several crop plants but susceptible to displacement by fungicide-resistant $B$. cinerea strains. Applied and environmental microbiology, AEM-01719. DOI: 10.1128/AEM.01719-15. 
41. Plūduma-Pauniņa, I., Gaile, Z., Bankina, B., \& Balodis, R. (2018). Field bean (Vicia faba 1.) yield and quality depending on some agrotechnical aspects. Agronomy Research, 16(1), 212-220.

42. Price, D. (1970). Tulip fire caused by Botrytis tulipae (Lib.) Lind; the leaf spotting phase. Journal of horticultural science, 45(3), 233-238.

43. Rossman, A. (2014). Lessons learned from moving to one scientific name for fungi. IMA Fungus, 5(1), 81-89.

44. Shipunov, A., Newcombe, G., Raghavendra, A.K., \& Anderson, C.L. (2008). Hidden diversity of endophytic fungi in an invasive plant. American Journal of Botany, 95(9), 1096-1108.

45. Staats, M., van Baarlen, P., \& van Kan, J.A. (2005). Molecular phylogeny of the plant pathogenic genus Botrytis and the evolution of host specificity. Molecular Biology and Evolution, 22(2), 333-346. DOI: 10.1093/molbev/msi020.

46. Taylor, P., Lindbeck, K., Chen, W., \& Ford, R. (2007). Lentil diseases. In Lentil (pp. 291-313). Springer, Dordrecht. DOI: 10.1007/978-1-4020-6313-8_18.

47. Tenberge, K.B. (2007). Morphology and cellular organisation in Botrytis interactions with plants. In Botrytis: Biology, pathology and control (pp. 67-84). Springer, Dordrecht. DOI: 10.1007/978-1-40202626-3 5.

48. Terefe, H., Fininsa, C., Sahile, S., \& Tesfaye, K. (2015). Effect of temperature on growth and sporulation of Botrytis fabae, and resistance reactions of faba bean against the pathogen. J Plant. Pathol. Microb, 6(7), 285.

49. Tivoli, B., Baranger, A., Avila, C.M., Banniza, S., Barbetti, M., Chen, W., ... Sadiki, M. (2006). Screening techniques and sources of resistance to foliar diseases caused by major necrotrophic fungi in grain legumes. Euphytica, 147(1-2), 223-253. DOI: 10.1007/s10681-006-3131-4.

50. Walker, A.S. (2016). Diversity within and between species of Botrytis. In Botrytis-the Fungus, the Pathogen and its Management in Agricultural Systems (pp. 91-125). Springer, Cham.

51. Walker, A.S., Gautier, A., Confais, J., Martinho, D., Viaud, M., Le Pêcheur, P., ... Fournier, E. (2011). Botrytis pseudocinerea, a new cryptic species causing gray mold in French vineyards in sympatry with Botrytis cinerea. Phytopathology, 101(12), 1433-1445. DOI: 10.1094/PHYTO-04-11-0104.

52. Watson, C.A., Reckling, M., Preissel, S., Bachinger, J., Bergkvist, G., Kuhlman, T., ... Stoddard, F.L. (2017). Grain Legume Production and Use in European Agricultural Systems, 144, 235-303. DOI: 10.1016/bs.agron.2017.03.003.

53. Willetts, H.J. (1997). Review: Morphology, development and evolution of stromata/sclerotia and macroconidia of the Sclerotiniaceae. Mycological Research, 101(8), 939-952.

54. Williamson, B., Tudzynski, B., Tudzynski, P., \& van Kan, J.A. (2007). Botrytis cinerea: the cause of grey mould disease. Molecular plant pathology, 8(5), 561-580.

55. Yohalem, D.S., Nielsen, K., \& Nicolaisen, M. (2003). Taxonomic and nomenclatural clarification of the onion neck rotting Botrytis species. Mycotaxon, 85, 175-182.

56. You, M.P., Yang, H.A., Sivasithamparam, K., \& Barbetti, M.J. (2009). A new leaf blight disease of Trifolium dasyurum caused by Botrytis fabae. European journal of plant pathology, 123(1), 99. DOI: 10.1007/s10658-008-9338-6.

57. Zhang, J., Wu, M.D., Li, G.Q., Yang, L., Yu, L., Jiang, D.H., ... Zhuang, W.Y. (2010). Botrytis fabiopsis, a new species causing chocolate spot of broad bean in central China. Mycologia, 102(5), 1114-1126. DOI: 10.3852/09-217.

58. Zhang, J., Zhang, L., Li, G.Q., Yang, L., Jiang, D.H., Zhuang, W.Y., \& Huang, H.C. (2010a). Botrytis sinoallii: a new species of the grey mould pathogen on Allium crops in China. Mycoscience, 51(6), 421431. DOI: 10.1007/S10267-010-0057-4.

59. Zhang, J., Yang, H., Yu, Q.Y., Wu, M.D., Yang, L., Zhuang, W.Y., ... Li, G.Q. (2016). Botrytis pyriformis sp. nov., a novel and likely saprophytic species of Botrytis. Mycologia, 108(4), 682-696. DOI: 10.3852/15340 . 